\title{
POSSIBILITIES FOR IMPROVING THE SPEED POWERQUALITIES OF THE FEMALE BASKETBALL PLAYERS
}

\author{
L. Kasabova* \\ Department of Physical Education and Sport, Business Faculty, \\ University of National and World Economy, Sofia. Bulgaria,
}

\begin{abstract}
An important task facing the educators teaching "Physical Education" - basketballin the Universities is the optimization of the development of the $>$ speed-force qualities of the students practicing this dynamic sport. The main objective of the study is to find and combine such combinations of workloads that meet the capabilities of middle qualification students, the subject of the study is to establish the dynamics of the changes in the work for speed - power qualities as a result of their application. In order to solve the target the following is applied: Theoretical analysis, Pedagogical experiment, Testing, mathematical-statistical analysis. The contingent of the survey is 40 students from the groups "sport of choice - basketball". Following the set tasks, we developed two models for the development of the speed-power most closely approaching the possibilities of the students in the conditions of the training process at the Universities. Six biomechanical indicators were demonstrated and followed at the jump using the BTS Freem - „G Sport”. The obtained results give us a reason to believe that the model combining plyometric and myometric mode of work and multiple jumps is more effective in the work of development the speed-power qualities,
\end{abstract}

Keywords: students, optimization, model, speed-power qualities

\section{INTRODUCTION}

One of the priority tasks faced by physical education teachers (basketball) in the Universities is the optimization of the process of developing the physical qualities and, in particular, of the speed-force qualities of the students trained by them. According to Russian researchers (1), "in the process of the pedagogical experiment the means and the methods of the special physical preparation are specified, that allow us to develop predominantly the speed-force qualities (the speed, the strength, the jump endurance), the jump of the students playing - basketball”.

One of the prior tasks of the training process in the basketball is the development of the speedpower qualities of the players.

\footnotetext{
*Correspondence to: Larissa Kasabova, Department of Physical Education and Sport, Business Faculty, University of National and World Economy, Sofia -1700, December 8th Blvd. Bulgaria,phone: (+359) 888369952; (+359 2) 862 90 75, e-mail: larissa.kasabova@gmail.com
}

According to a number of authors, the muscle strength depends on anatomical, biomechanical, physiological, biochemical and psychological factors that affect the body at the same time $(2,3)$. By interpreting the strengths qualities of the basketball players, the same author believes that "the preparation should be directed to building an blasting force, special strength durability (speed and jumping) and power agility". When building the "blasting force", he uses a combined training method in which he alternates the load not only in terms of size, but also in terms of working modes (receding, overcoming and isometric). Except him, other authors (4) recommend a short load at resistance level of up to $20 \%$ of the maximum ratio between light and medium weights of 1: 5 .

Some researchers $(3,5)$ distinguish the dynamic power into two main types:

1. Explosive force when the resistance does not reach its limit values and is accompanied with maximum acceleration. 
2. Quick force, which also manifests itself in undefined values but also the acceleration is lower than the maximum.

According to the second author, when it is worked on developing the velocity-force qualities simultaneously with other specific qualities, the synthetic method of influence is used, it is worked on their simultaneous development.

According to Stoilov, I. (6) "The main methodical problem in the training for dynamic force is the maximal activation of the fast muscle fibers. For this purpose, strength exercises do not hamper or stop the circulation, which is achieved with greater load variation - tension must be coupled with muscle loosening.

When it is necessary to improve the advantage if one of the qualities, the analytical method is used, the loads are selectively chosen. To improve the internal and intra-muscular coordination, he proposes a third variational method of alternating loads with a high or a competitive load.

We encounter similar developments and suggestions in the works of Verhošansky, Y. (7), who by accident finds that by increasing the level of qualification of the athlete the growth of the explosive force decreases. To avoid this negativity, he suggests the use of plyometric exercises that are done together with a momently pre-stretched muscles (jumps from high to low and again to high).

Other authors (8-10) share the opinion that only with the simultaneous improvement of the speed and power elements of the movement, an improvement of the speed-power and velocity can be expected.

From the brief overview, it is clear that the specialists are looking for the most appropriate combination between the magnitude of the impedance (load), the speed of the performance and the training method to achieve the desired result.

\section{OBJECTIVE OF THE STUDY}

The main objective of the present study is to find such combinations of workloads that meet the capabilities of female basketball students with an average level of qualification.

\section{TASKS OF THE STUDY}

1. To develop two models for impact and development of the velocity of female students practicing basketball that are as close as possible to their abilities and the training conditions in the training-educational process in the university.

2. To investigate some biomechanical features shown during the jump, using the appropriate equipment.

3. To establish the speed in the growth of both groups.

\section{ORGANIZATION OF \\ THE IVESTIGATION}

The subject of the study is the dynamic of the changes in the speed-power qualities of students from the groups "sport - optional basketball" from the University of National and World Economy due to the application of the different training models developed.

The contingent of the study is 40 students from the "Sports Optional Basketball" groups of the University of National and World Economy, which were tested in advance to equip the experimental groups equally.

Separated into two groups - first $(E G-1)$ and second $(E G-2)$. There are two formed groups of 20 female students - basketball players. The groups worked on the established models (Table 1 and Table 2), four months, two activities per week and a total of thirty-four workouts. The tests were conducted at the beginning and end of the experiment, the results were statistically processed.

For success control is used a special test „Counter Mouvement Jump (CMJ), done with a specialized equipment „BTS Freem-G30” that belongs to the Center for Scientific and Applied Activity in Sport in National Sports Academy „Vasil Levski”, Sofia. This is a maximum jump that is performed with hands on the hips, from a semi-clock position with a bend in the knees of $90^{\circ}$. The height of the jump (h) is defiined by the time of the flight phase ,t" and the earth acceleration " $\mathrm{g}$ " (expressed by coefficient $\mathrm{k}=$ 1,22583125 ) with the formula

$\mathbf{h}=\mathbf{k} \cdot \mathbf{t}^{2}$

Five other metrics are displayed: Jump force $(\mathrm{kg} / \mathrm{N})$; Landing force $(\mathrm{kg} / \mathrm{N})$; Maximum concentric force $(\mathrm{kg} / \mathrm{N})$; Peak velocity $(\mathrm{m} / \mathrm{s})$; Rebound acceleration $(\mathrm{m} / \mathrm{s})$ using the "BTS Freem" - G30. We also measured the anthropometric indicators: height and weight.

The groups worked on the established programs (models) - four months, with two activities per week and a total of thirty-four workouts. 
Table 1. Power-training model of the basketball players in EG-1

\begin{tabular}{|c|c|c|c|c|}
\hline Indicators: & $\begin{array}{c}\text { With } \\
\text { aggravations }\end{array}$ & $\begin{array}{c}\text { Intensity } \\
(\%)\end{array}$ & $\begin{array}{c}\text { Volume } \\
\text { in a training } \\
(\mathrm{kg})\end{array}$ & $\begin{array}{l}\text { With jumps } \\
\text { and leaps } \\
\text { (cnt) }\end{array}$ \\
\hline $\begin{array}{l}\text { First group (EG -1) } \\
\text { First training: } \\
\text { a. resistance } \\
\text { (\%); } \\
\text { b. repeats in a single series (cnt.) } \\
\text { c. series (cnt.) } \\
\text { d. pauses (min.) } \\
\text { e. method }\end{array}$ & $\begin{array}{l}75 \% \\
\text { of the maximum } \\
10 \\
4 \\
0 / 3,5 \\
\text { myometric- } \\
\text { analytical } \\
\end{array}$ & 90 & 2400 & $\begin{array}{l}4 \times 10 \text { Plyometric } \\
\text { and } \\
5 \times 30 \text { multiple } \\
\text { jumps (myometric) } \\
\text { plyometric } \\
\text { and myometric }\end{array}$ \\
\hline $\begin{array}{l}\text { Second training: } \\
\text { a. resistance } \\
(\%) ; \\
\text { b. repeats in a single series (cnt.) } \\
\text { c. series (cnt.) } \\
\text { d. pauses (min.) } \\
\text { e. method }\end{array}$ & $\begin{array}{l}90 \% \\
\text { of the maximum } \\
7-8 \\
5-6 \\
0 / 4 \\
\text { myometric- } \\
\text { plyometric }\end{array}$ & $98-100$ & 2800 & $\begin{array}{l}4 \times 10 \text { plyometric } \\
\text { and } \\
5 \times 30 \text { multiple } \\
\text { jumps (myometric) } \\
\text { plyometric } \\
\text { and myometric }\end{array}$ \\
\hline
\end{tabular}

Table 2. Power-training model of the basketball players in EG-2

\begin{tabular}{|c|c|c|c|c|}
\hline Indicators: & $\begin{array}{c}\text { With } \\
\text { aggravations }\end{array}$ & $\begin{array}{c}\text { Intensity } \\
\text { (\%) }\end{array}$ & $\begin{array}{c}\text { Volume } \\
\text { in a training } \\
(\mathbf{k g})\end{array}$ & $\begin{array}{l}\text { With jumps } \\
\text { and leaps } \\
\text { (cnt) }\end{array}$ \\
\hline $\begin{array}{l}\text { Second group }(\mathbf{E G}-\mathbf{2}) \\
\text { First training: } \\
\text { a. resistance } \\
(\%) \text {; } \\
\text { b. repeats in a single series (cnt.) } \\
\text { c. series (cnt.) } \\
\text { d. pauses (min.) } \\
\text { e. method }\end{array}$ & $\begin{array}{l}85 \% \text { of the } \\
\text { maximum } \\
75+85+90+85+75 \\
2 \\
2+3+3+3+2 \\
\text { pyramid, } \\
\text { repeated, } \\
\text { synthetic }\end{array}$ & 85 & 2400 & $\begin{array}{l}2 \text { series } 4 \times 30 \mathrm{~m} \text {. } \\
\text { Jumps with lifting } \\
\text { the knees up to the } \\
\text { chests } \\
\text { repeated, } \\
\text { myometric }\end{array}$ \\
\hline $\begin{array}{l}\text { Second training: } \\
\text { a. resistance (\%) } \\
\text { b. repeats in a single series (cnt.) } \\
\text { c. series (cnt.) } \\
\text { d pauses (min.) } \\
\text { e. method }\end{array}$ & \begin{tabular}{|l}
$75 \%$ \\
10 \\
5 \\
$0 / 4$ \\
repeated, \\
synthetic
\end{tabular} & $98-100$ & 2800 & $\begin{array}{l}\text { series } 4 \times 30 \mathrm{~m} . \\
\text { Jumps with lifting } \\
\text { the knees up to the } \\
\text { chests } \\
\text { repeated, } \\
\text { myometric }\end{array}$ \\
\hline
\end{tabular}

The testing are performed at the beginning and the end of the experiment, the results are statistically processed.

The results, starting and ending, of the two experimental groups of basketball female students are shown on Table 3 and Table 4.

\section{ANALYSIS OF THE RESULTS}

The two groups of basketball players surveyed, have approximately the same training volume of power workout using weights and multiple jumps
(Table 1). The differences are in the used training methods. The first group (EG-1) in the work uses the method of the analytical (selective) effect, with the help of the aggravation, with expressed myometric (concentric) muscular effort . The jumping exercise includes mostly plent imetal (eccentric) muscular effort, such as jumping on stairs and jumping from high to low and high again. 
Table 3. Results of the $1^{\text {st }}$ and $2^{\text {nd }}$ testing in FIRST experimental group (I-st EG)

\begin{tabular}{|c|c|c|c|c|c|c|c|c|c|c|c|}
\hline \multirow[b]{2}{*}{ Indicators: } & \multirow[b]{2}{*}{ Testing №- } & \multirow[b]{2}{*}{$\mathbf{N}$} & \multirow[b]{2}{*}{$\min$} & \multirow[b]{2}{*}{$\max$} & \multirow[b]{2}{*}{ M } & \multirow[b]{2}{*}{ SD } & \multicolumn{2}{|c|}{ difference } & \multirow[b]{2}{*}{$\mathbf{t}$} & \multirow[b]{2}{*}{ Sig } & \multirow{2}{*}{\begin{tabular}{|c|} 
contribution \\
$\%$
\end{tabular}} \\
\hline & & & & & & & \begin{tabular}{|l|} 
abs. \\
\end{tabular} & relative & & & \\
\hline \multirow[t]{2}{*}{ 1. Jump height (sm) } & 1 & 20 & 21,4 & 52,4 & 39,04 & 8,751 & & & & & \\
\hline & 2 & 20 & 28,5 & 53,8 & 41,85 & 10,229 & 2,810 & 7,12 & 4,367 & 0,003 & 9,74 \\
\hline \multirow{2}{*}{$\begin{array}{l}\text { 2. Power of the jump } \\
(\mathrm{kg} / \mathrm{N})\end{array}$} & 1 & 20 & 0,34 & 0,89 & 0,645 & 0,352 & & & & & \\
\hline & 2 & 20 & 0,49 & 1,03 & 0,751 & 0,617 & 0,106 & 16,4 & 2,450 & 0,160 & 22,23 \\
\hline \multirow{2}{*}{$\begin{array}{l}\text { 3. Landing force } \\
(\mathrm{kg} / \mathrm{N})\end{array}$} & 1 & 20 & 0,68 & 2,25 & 1,590 & 0,342 & & & & & \\
\hline & 2 & 20 & 0,98 & 2,29 & 1,669 & 0,406 & 0,079 & 4,96 & 2,603 & 0,764 & 6,72 \\
\hline \multirow{2}{*}{$\begin{array}{l}\text { 4.Maximum } \\
\text { concentric force } \\
(\mathrm{kg} / \mathrm{N})\end{array}$} & 1 & 20 & 0,47 & 2,65 & 1,398 & 8,744 & & & & & \\
\hline & 2 & 20 & 0,68 & 2,78 & 1,732 & 0,738 & 0,334 & 23,89 & 2,787 & 0,295 & 32,38 \\
\hline \multirow[t]{2}{*}{ 5. Peak speed $(\mathrm{m} / \mathrm{s})$} & 1 & 20 & 1,57 & 2,93 & 2,356 & 0,483 & & & & & \\
\hline & 2 & 20 & 1,51 & 3,09 & 2,603 & 0,395 & 0,247 & 10,48 & 2,499 & 0,560 & 14,20 \\
\hline \multirow{2}{*}{$\begin{array}{l}\text { 6.Jump acceleration } \\
(\mathrm{m} / \mathrm{s})\end{array}$} & 1 & 20 & 1,55 & 2,93 & 2,351 & 0,488 & & & & & \\
\hline & 2 & 20 & 1,56 & 3,11 & 2,606 & 0,255 & 0,255 & 10,84 & 2,111 & 0,860 & 14,69 \\
\hline \multirow[t]{2}{*}{ 7. Height (sm ) } & 1 & 20 & 161,3 & 188,0 & 177,3 & 9,153 & & & & & \\
\hline & 2 & 20 & 161,8 & 188,0 & 177,5 & 9,178 & 0,020 & 0,112 & 0,899 & 0,382 & \\
\hline \multirow[t]{2}{*}{ 8. Body weight (kg) } & 1 & 20 & 47,1 & 73,0 & 65,0 & 14,486 & & & & & \\
\hline & 2 & 20 & 46,6 & 71,0 & 63,8 & 14,966 & 1,20 & 1,84 & 2,227 & 0,039 & \\
\hline
\end{tabular}

Table 4. Results of the $1^{\text {st }}$ and $2^{\text {nd }}$ testing in the SECOND experimental group (II-nd EG)

\begin{tabular}{|c|c|c|c|c|c|c|c|c|c|c|c|}
\hline \multirow[b]{2}{*}{ Indicators: } & \multirow[b]{2}{*}{$\begin{array}{l}\text { Testing } \\
\text { №- }\end{array}$} & \multirow[b]{2}{*}{$\mathbf{N}$} & \multirow[b]{2}{*}{$\min$} & \multirow[b]{2}{*}{$\max$} & \multirow[b]{2}{*}{ M } & \multirow[b]{2}{*}{ SD } & \multicolumn{2}{|c|}{ difference } & \multirow[b]{2}{*}{ t } & \multirow[b]{2}{*}{ Sig } & \multirow{2}{*}{\begin{tabular}{|c|} 
contribution \\
$\%$
\end{tabular}} \\
\hline & & & & & & & abs & relative & & & \\
\hline \multirow[t]{2}{*}{ 1. Jump height (sm) } & 1 & 20 & 21,9 & 51,9 & 38,3 & 8,211 & & & & & \\
\hline & 2 & 20 & 26,6 & 52,9 & 40,9 & 9,640 & 1,46 & 3,77 & 5,211 & 0,012 & 7,70 \\
\hline \multirow{2}{*}{$\begin{array}{l}\text { 2.Power of the jump } \\
(\mathrm{kg} / \mathrm{N})\end{array}$} & 1 & 20 & 0,38 & 0,77 & 0,61 & 0,297 & & & & & \\
\hline & 2 & 20 & 0,42 & 0,96 & 0,681 & 0,814 & 0,087 & 14,47 & 1,972 & 0,019 & 29,59 \\
\hline \multirow{2}{*}{ 3. Landing force $(\mathrm{kg} / \mathrm{N})$} & 1 & 20 & 0,63 & 2,20 & 1,579 & 0,316 & & & & & \\
\hline & 2 & 20 & 0,74 & 2,26 & 1,622 & 0,503 & 0,043 & 2,72 & 1,897 & 0,617 & 5,56 \\
\hline \multirow{2}{*}{$\begin{array}{l}\text { 4.Maximum concentric } \\
\text { force }(\mathrm{kg} / \mathrm{N})\end{array}$} & 1 & 20 & 0,53 & 2,47 & 1,281 & 6,941 & & & & & \\
\hline & 2 & 20 & 0,61 & 2,56 & 1,456 & 4,211 & 0,275 & 13,66 & 1,714 & 0,209 & 27,93 \\
\hline \multirow{2}{*}{$\begin{array}{l}\text { 5. Peak speed } \\
(\mathrm{m} / \mathrm{s})\end{array}$} & 1 & 20 & 1,52 & 2,78 & 2,018 & 0,511 & & & & & \\
\hline & 2 & 20 & 1,54 & 2,99 & 2,127 & 0,392 & 0,109 & 5,40 & 1,396 & 0,500 & 11,04 \\
\hline \multirow{2}{*}{$\begin{array}{l}\text { 6.Jump acceleration } \\
(\mathrm{m} / \mathrm{s})\end{array}$} & 1 & 20 & 1,46 & 2,48 & 2,090 & 0,317 & & & & & \\
\hline & 2 & 20 & 1,51 & 2,81 & 2,276 & 0,331 & 0,186 & 8,89 & 1,129 & 0,788 & 18,17 \\
\hline \multirow[t]{2}{*}{ 7. Height (sm ) } & 1 & 20 & 157,7 & 178,2 & 171,4 & 11,217 & & & & & \\
\hline & 2 & 20 & 159,3 & 178,4 & 171,6 & 8,009 & 0,200 & 0,116 & 0,623 & 0,319 & \\
\hline \multirow{2}{*}{$\begin{array}{l}\text { 8. Body weight } \\
(\mathrm{kg})\end{array}$} & 1 & 20 & 46,3 & 71,5 & 64,6 & 12,753 & & & & & \\
\hline & 2 & 20 & 46,0 & 70,2 & 63,4 & 13,815 & 1,200 & 1,85 & 2,090 & 0,051 & \\
\hline
\end{tabular}

The second group (EG-2) uses the pyramidal and the repeat method, when working with weights, and in the jumps uses the myometric method with multiple length jumps $(20-30 \mathrm{~m}$.).

When performing the steady jump test with both legs, with no hands being used, there are six dynamic stats pointed out.

In the first record of height of the jump registered by the apparatus between the two groups, there are significant differences. At approximately the same exit levels, the change in absolute and relative values in the first group $(2,310 \mathrm{~cm}$.) are twice higher than those of the second group (1,460 см.) with much higher confidence number $(4,367)$, but so is the number of the second group $(5,211)$. This statistical reliability shows that both types of workout have positive changes, but the larger numbers in the first group are obviously because of the used training method. In Table $\mathbf{1}$ is visible that these are exercises with resistance close to the limit (90\%-100\%), large amount of repeats (8-10) and continues break (3,5-4,0 min.). The lower resistance (75\%) allows an action with higher speed, which induces muscle protein synthesis in cellular fibers, and often due to the disruptive synthesis of proteins 
that provide contractions leads to a certain muscle hypertrophy.

The jump strength expressed in $\mathrm{kg} / \mathrm{N}$ is 0.019 $\mathrm{kg} / \mathrm{N}$ is higher in the first group. Obviously this factor, albeit with minimal variation, leads to a significant increase in the acceleration and the height of the jump.

The force of ejection and the height of the bounce are closely related to the landing force indicator. The body weight of the basketball players is also influenced here. The differences between the two groups are insignificant and therefore the higher value of this indicator found in the second group shows a lesser technical performance of the jump and a hard landing. With values of $1.80-1.90$, we report a relatively high confidence probability (Pt 0.93-0.94\%) where the true average values of the measure are within 1.5-2.0c. Changes in the first group are greater, due to the bigger height of the jump and consequently the greater force exerted on the depression support

The used training methodology with the first group, which includes, as muscular-muscle stress-strain-to-concentric-amplitudes-

concentric-myometric stresses, as well as eccentric-plyometric stresses - by muscle stretching, leads to a greater influence on the maximal muscular contraction (force). The relative changes in the two groups are significant (respectively for the first group $23.89 \%$ and for the second $13.66 \%$ ) for differences and the confidence probability of the indicator ( $\mathrm{Pt} 0.991$ for the first and $0.912 \%$ for the second group).

The presence of greater force in the ejection is also related to the magnitude of the peak velocity at the separation from the support.

The maximum values of this indicator, as well as the absolute and relative indicators in the first group, are twice as good. The peak velocity in this group has increased by $0.247 \mathrm{~m} / \mathrm{s}$, while in the second it was $0.109 \mathrm{~m} / \mathrm{s}$. The relative increase is $10.48 \%$ and $5.40 \%$.

The last tested indicator is the acceleration of the body during the bounce and the separation from the support. In principle, it depends on the strength of the lower limbs (four-headed hip and trigeminal muscle), for which a greater effect has had the training which the first group has been put on.

Complex, the examined power and velocity indicators give an objective judgment of which elements need to be refined to improve the rebound height of the support.

\section{CONCLUSIONS AND RECOMMENDATIONS}

1. The proposed training methodology, combining a plyometric and myometric mode of work with corresponding power training that includes weight and multiple jumps, gives a significant higher growth for improving the bounce of the basketball players.

2. With the highest relative contribution for the height of the jump in the first group are the maximal concentric force $(32,38 \%)$ and the force of the jump $(22,23 \%)$. In the second group the force of the bounce has contribution of $29,59 \%$, and the maximal concentric force of $27,93 \%$. Influence here appears to be the acceleration achieved during the jump $-18,17 \%$.

3 . The relative contribution to the development of the bounce in the first group is explained with $73,76 \%$ of total significance of the five examined indicators, while in the second group it is just $48,91 \%$.

\section{REFERENCES}

1. Tkhazeplova G.N., Norik L.V., Nalchik Popova L.S., Technology of training physical qualities of basketball players. UDC 796, 797, 798, 799 Sport science of Russia: state and development prospects: materials of the All-Russian scientific-practical conference dedicated to the 90th anniversary of the journal "Theory and Practice of Physical Culture" December 3-5, 2015 / Ed. L.I.Lubysheva, S.N. Litvinenko. - M .: FGBOU VPO “RSUFKSMiT”, 2015. p. 360, Russia

2. Zhelyazkov, Tsv, D. Dasheva, Fundamentals of Sports Workout, C, Gera Art Ltd., 2002

3. Zhelyazkov, Tsv. Theory and Methodology of Sports Training, C, MF, 1986

4. Seluyanov, V.et all. Theory and practice of the use of didactics developing training, $\mathrm{M}$, 1996

5. Kuznetsov, V. V. Special athlete strength training. M., "Soviet Russia", 1975.

6. Stoilov, I. Futzal - Complex Approach for Preparation, Monograph, UNWE Complex, Sofia, 2019

7. Verkhoshansky, U, Basics of Special Strength Training in Sport. FSC. M., 19708.

8. Bowerman, W., W. Freeman, High Performance Training for Track and Field fester Press, Illinois, 1991.

9. Dick, F. No speed limits. NSA, 2/3, 1996.

10. Harre, D., Training der Schnelligkeitsport und Gesundheit. Verlag, Berlin. 1991 